\title{
Effect of L-Arginin on Placental Hipoxia Inducible Factor -1-Alpha (HIF-1-A) Expression at Preeclampsia Mice Models
}

\author{
Nutria Widya Purna Anggraini'), Sri Sulistyowati²), \\ Besari Adi Pramono3), Herman Kristanto3)
${ }^{1)}$ Department of Obstetrics and Gynecology, Faculty of Medicine, Universitas Sebelas Maret/ dr. Moewardi General Hospital, Surakarta Universitas Sebelas Maret Hospital, Surakarta
3)Department of Obstetrics and Gynecology, Faculty of Medicine, Diponegoro University/ \\ 2)Department of Obstetrics and Gynecology, Faculty of Medicine, Universitas Sebelas Maret/ \\ Kariadi General Hospital, Semarang
}

\section{ABSTRACT}

Background: Placental hypoxia is one of the theories that cause preeclampsia. In placental hypoxia of preeclampsia, there is an increase of $\mathrm{Hi}-$ poxia Inducible Factor 1 Alpha (HIF-1-A) expression as a response to hypoxia. L-Arginine administration through the L-Arginine-Nitric Oxide pathway is expected to improve placental hypoxia. This study aimed to examine the effect of LArginin on placental HIF-1-A expression at preeclampsia mice models.

Subjects and Method: Experimental study with parallel group post-test only design. The study was carried out at the Veterinary Medicine Faculty of Airlangga University. Thirty six preeclampsia mice models were made with intravenous injection 10ng anti-Qa-2 on day 1-4 of pregnancy. They were divided into 2 groups: (1)18 mice without treatment (control) and (2) 18 mice were given L-Arginin $200 \mathrm{mg} / \mathrm{kgBW} /$ day on day 7-15 of pregnancy. They were terminated on day 16 then immunohistochemistry examination of HIF-1-A expression was done on the placental samples. The dependent variable was placental
Hipoxia Inducible Factor-1-Alpha (HIF-1-A) expression. The independent variables were L-Arginin administration. HIF-1-A expression was measured by H-Score method. The data were analyzed by t-test.

Results: The mean of placental HIF-1-A expressions of treatment group was lower (Mean= 7.98; $\mathrm{SD}=9.35$ ) than control group (Mean=41.95; $\mathrm{SD}=32.20)$, and it was statistically significant ( $\mathrm{p}$ $<0.001)$.

Conclusion: L-Arginin reduces the Placental Hypoxia Inducible Factor Alpha (HIF-1-A) expression on preeclampsia mice model.

Keywords: L-Arginine, HIF-1-A, Preeclampsia

\section{Correspondence:}

Nutria Widya Purna Anggraini. Department of Obstetrics and Gynecology, Faculty of Medicine Universitas Sebelas Maret/ Dr. Moewardi General Hospital Surakarta. Jl Kolonel Sutarto 132, Surakarta, Central Java, Indonesia. Email :nutria_dr@staff.uns.ac.id. Mobile: o8122651819.

Cite this as:

Anggraini NWP, Sulistyowati S, Pramono BA, Kristanto H (2020). Effect of L- Arginin on Placental Hipoxia Inducible Factor -1-Alpha (HIF-1-A) Expression at Preeclampsia Mice Models. Indones J Med. 05(03): 191-199. https://doi.org/10.26911/theijmed.2020.05.03.03.

cc) (i) (2) Indonesian Journal of Medicine is licensed under a Creative Commons (c)

\section{BACKGROUND}

Preeclampsia is one of the most common problems during pregnancy worldwide and is the leading cause of maternal and infant death (Roberts, 2013). Diagnosis of preeclampsia is established based on the presence of hypertension, proteinuria, and other organ system disorders in 20-week return (Koffreh, 2014).

In Indonesia preeclampsia remains the three highest classic causes of maternal mortality, in addition to infection and hemorrhage (Himpunan Kedokteran Fetomaternal, 
2017. Data in Central Java province by 2015 , preeclampsia is still the leading cause of maternal mortality by $26.34 \%$ (Provincial Health Office of Central Java, 2015).

Placental hypoxia in preeclampsia happened because of the reduce uteroplacental perfussion, thus expenditure of placental factors including over-production of excessive free radicals, and oxidative stress then trigger endothelial dysfunction in the placenta and systemic (Hubel,2009).In oxidative stress condition, there is an imbalance between pro angiogenic factors such as Placental Growth Factor (PlGF) and Vascular Endothelial Growth Factor (VEGF) with anti-angiogenic factor Soluble Fms-Like Tyrosine Kinase 1 (sFlt-1) and Soluble Endoglin (zinc). The condition of hypoxia and imbalance between angiogenic and anti angiogenic factors will affect the process of angiogenesis, vasculogenesis and the development of placenta (Lyall and Bellfort,2007).

Placental hypoxic conditions causing excessive expression of HypoxiaInducible Factor-1 (HIF-1) in placental tissue and blood. HIF-1 is an important element in the regulation of transcription of various genes that appear in hypoxic conditions (Wantania et al,2013).HIF-1 consists of two sub-units, Hipoxia Inducible Factor-1 Betha (HIF-1 $\beta$ ) and Hipoxia Inducible Factor-1-Alpha (HIF1a). HIF-1a or HIF-1-A play an important role in hypoxic signaling, as well as regulate trophoblast differentiation and expression of Transforming Growth Factor $\beta_{3}$ (TGF $\beta 3$ ) involved in the oxygen differentiation process in placental development as well as various pregnancy disorders (Patel et al., 2010). HIF1-A much expressed on placental tissue of preeclampsia, so it is said that HIF-1-A expression is a good marker of placental hypoxia (Reshef, 2012). Hypoxia conditionin the placenta results in increased production of sFLT-1, sENG, Endothelin-1, and AT1-AA, which mediated by HIF -1-A, and a decrease in VEGF, sENG-1, leading to maternal endothelial damage, and the manifestation of preeclampsia (Woods et al., 2011).

Based on the pathogenesis of preeclampsia above, it is expected to give some new insights into preeclampsia therapy. Some researchers have tried to treat preeclampsia before clinical (preclinical) symptoms are made in animals experimental (mice) (Burke and Karumanchi, 2013). This animal studies based on consideration, it would be difficultin humans to see abnormalities that occur before clinical symptoms appear in the second trimester (Sulistyowati, 2017).

L-Arginin is a semi essential amino acid that induces Nitrit Oxide (NO), a powerful antioxidant (Facchinetty, 2017). L-ArginineNO pathway is believed to play a role in preeclampsia, where NO from maternal circulation will cross into placenta and dilate vascular placental villi, increase the number of vascular villi, vasodilatation of the lumen and muscle, also blood vessel walls appear thinner (Al-Bayati et al., 2014). NO in placental endothelium, umbilical cord, contribute to maintain vascular tone and reduce action of vasoconstrictors such as endothelin (ET-1) and thromboxane (Soetrisno et al., 2017).

In this study, the authors tried to expose the pathogenesis of preeclampsia placental hypoxia, associated with preeclampsia therapy before a manifestation or clinical symptoms. Improvement of placental hypoxia condition, with administration of vasodilatory nutrient supplementation, L-Arginin.

\section{SUBJECTS AND METHOD}

\section{Study Design}

This study is an experimental study with parallel group posttest only design. The study was carried out at The study was at Animal Experimental and Biomedical Laboratory of the Faculty of Veterinary Medicine, AirlanggaUniversity. 


\section{Study Sample}

Animal study using mice, with inclusion criteria are female mice (Mus musculus) Swiss strain obtained from central Veterinaria Farma Surabaya. In this study obtained female mice aged 3 months, healthy, weight 20-25 grams.

The number of samples was determined by Federer's formula (Supranto, 2000). The number of samples was $16(\mathrm{n}=16)$ and to avoid the decrease number of samples due to death, sickness, premature or weight loss during the study by $10 \%$, the number of samples each group were 18 , so that total sample of the study were 36 mice.

The technique or sampling method in this study were made preeclampsia mice models by giving injection of 10ng iv anti-Qa-2 (homolog to human HLA-G) on days 1-4 of pregnancy. Then divided into 2 groups, first without treatment or administration of L-Arginin(control), the second group was administrated L-Arginin $200 \mathrm{mg} / \mathrm{kgBW} /$ day on days 7-15 of pregnancy. On day 16 it was terminated, and took the placental sample then examined with immunohistochemical of HIF1-A expression. Results are assessed semi quantitatively according to the $\mathrm{H}$-Score method.

\section{Study Variables}

The dependent variable was placental Hipoxia Inducible Factor-1-Alpha (HIF-1-A) expression. The independent variables were LArginin administration.

\section{Operational Definition of Variables} L-Arginin was defined as essential amino acids specifically synthesized by intestinal epithelial cells with dosage 200mg/ kgBW/ oral/day, given at days 7 th-15th of pregnancy Placental Hipoxia Inducible Factor -1-Alpha (HIF-1-A) Expression was defined as immunohistochemical expression hypoxisubunit of a heterodimeric transcription factor hypoxia- inducible factor 1 (HIF-1) that is encoded by the HIF-1-A gene.

\section{Study Instruments}

HIF-1-A expression was measured by an immunohistochemical method.

\section{Data Analysis}

Data were analyzed by unpaired t-test when normal data distribution, and Mann Whitney's test when the data distribution was not normal. The statistical calculation in this study used the significance level of 0.05 (confident interval 95\%).

\section{Research Ethics}

Ethical clearance No: 648-KE 19 October 2017.

\section{RESULTS}

A. Animal and Fetal Characteristic

Animal and Fetal Characteristic in each group. Table 1 shows the characteristic of sample. At table 2 shows mean body weight of mice after treatment L-Arginin administration, body weight of mice in case group (Mean= 29.9; $\mathrm{SD}=2.32$ ) was higher than control group $($ Mean $=27.7 ; \mathrm{SD}=3.72)$, ant it was statistically significant $(\mathrm{p}=0.042)$.

The number of fetuses in the case group (Mean= 8.8; $\mathrm{SD}=1.47$ ) was higher than in the control group (Mean=6.6; $\mathrm{SD}=2.06)$, ant it was statistically significant $(\mathrm{p}=0.002)$.

The mean fetal weight in the case group (Mean=0.4; $\mathrm{SD}=0.15$ ) was heavier than the control group $(\mathrm{Mean}=0.3 ; \mathrm{SD}=0.08)$, and it was statistically significant $(\mathrm{p}=0.002)$.

The mean length of fetus in case group (Mean=2.0; $\mathrm{SD}=0.41$ ) was longer than the control group (Mean= 1.6; $\mathrm{SD}=0.41)$, and it was statistically significant $(\mathrm{p}=0.005)$.

The mean weight of placenta in the case group (Mean=0.2; $\mathrm{SD}=0.05$ ) was heavier than the control group (Mean= $0.1 ; \mathrm{SD}=$ $0.04)$, and it was statistically significant $(\mathrm{p}=$ 0.003). 
Anggraini et al./ Effect of L- Arginin on Placental Hipoxia Inducible Factor -1-Alpha

Table 1. Sample Characteristics

\begin{tabular}{lccccc}
\hline Variables & N & Mean & SD & Min. & Max. \\
\hline Body Weight (gram) & 36 & 22.8 & 1.72 & 20.0 & 25.0 \\
Number of fetus & 36 & 6.6 & 2.06 & 4.0 & 10.0 \\
Weight of fetus (gram) & 36 & 0.3 & 0.08 & 0.2 & 0.4 \\
Length of fetus (cm) & 36 & 1.6 & 0.41 & 0.9 & 2.1 \\
Weight of placenta(gram) & 36 & 0.1 & 0.04 & 0.1 & 0.2 \\
\hline
\end{tabular}

Table 2. Mean difference after treatment $L$-Arginin administration between control and case groups

\begin{tabular}{|c|c|c|c|c|}
\hline Variables & $\mathbf{N}$ & Mean & SD & $\mathbf{p}$ \\
\hline \multicolumn{5}{|c|}{ Body Weight (gram) } \\
\hline Control group & 18 & 27.7 & 3.72 & \multirow[t]{2}{*}{0.042} \\
\hline Case group & 18 & 29.9 & 2.32 & \\
\hline \multicolumn{5}{|c|}{ Number of fetus } \\
\hline Control group & 18 & 6.6 & 2.06 & \multirow[t]{2}{*}{0.002} \\
\hline Case group & 18 & 8.8 & 1.47 & \\
\hline \multicolumn{5}{|c|}{ Weight of fetus (gram) } \\
\hline Control group & 18 & 0.3 & 0.08 & \multirow[t]{2}{*}{0.004} \\
\hline Case group & 18 & 0.4 & 0.15 & \\
\hline \multicolumn{5}{|c|}{ Length of fetus (cm) } \\
\hline Control group & 18 & 1.6 & 0.41 & \multirow[t]{2}{*}{0.005} \\
\hline Case group & 18 & 2.0 & 0.41 & \\
\hline \multicolumn{5}{|c|}{ Weight of placenta (gram) } \\
\hline Control group & 18 & 0.1 & 0.04 & \multirow[t]{2}{*}{0.003} \\
\hline Case group & 18 & 0.2 & 0.05 & \\
\hline
\end{tabular}

B. Placental Hipoxia Inducible Factor -1-Alpha (HIF-1-A) Expression

Tabel 3. HIF-1-A placental expression in each group

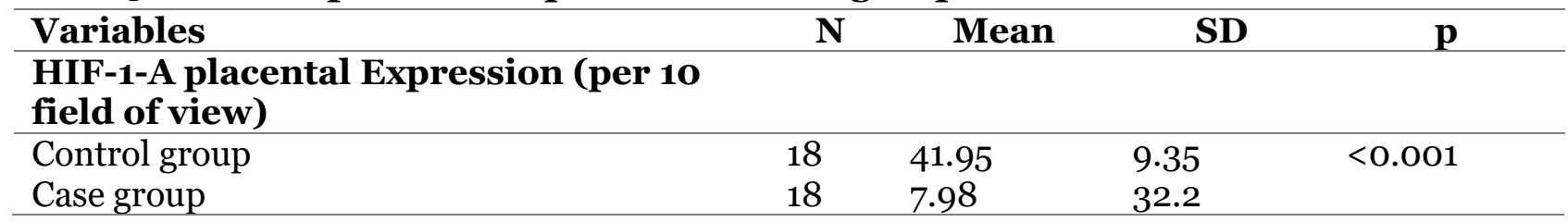

Table 3 showed the mean difference of HIF1-A placental expression in both case and control groups. Table 3 showed that HIF-1-A placental expression in the case group (Mean= 7.98; $\mathrm{SD}=9.35$ ) was lower than in the control group $(\mathrm{Mean}=41.95 ; \mathrm{SD}=32.20)$, and it was statistically significant $(\mathrm{p}<0.001)$. Comparison of HIF-1-A placental expression among the study groups was also shown in Figure 1. 

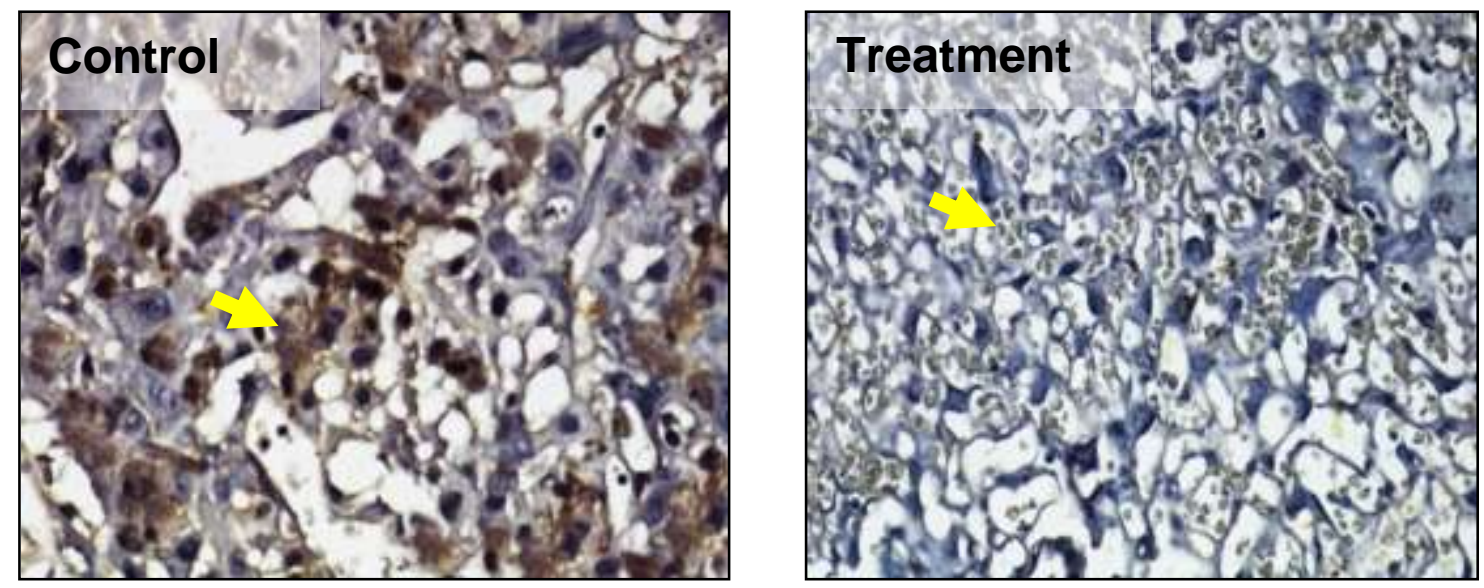

Figure 1. The expression of HIF-1-A in PE mice model,is brown chromogen in placental trophoblast cells (arrows) in the control is stronger (brown chromogen) than treatment groups (weak HIF-1-expression up to absence of HIF-1-A expression).(Immunohistochemical staining, 40oX magnification, Nikon H6ooL microscope, DS Fi2 300 megapixel amera_DS Fi2 camera)

\section{DISCUSSION}

\section{Characteristics of the sample}

The number of fetus in the treatment group (Mean= 8.8; $\mathrm{SD}=1.47$ ) was higher than in control group (Mean=6.6; $\mathrm{SD}=2.06$ ), with $\mathrm{p}=0.002$. This is in accordance with previous studies on pigs and sheep. A study by Gao (2011), showed that pigs receiving L-Arginine the number of live-born pigs much more than control group, this is possible because, administration of L-Arginine increases amino acids, as well as the production of estrogen and progesterone hormones that improve fetal well-being conditions as well survival of the fetus. Lassala et al. (2011), shows that administration of L-Arginine does not affect the number of sheep born (Lassala et al., 2011). However L- Arginine reduces ( $p$ $<0.05$ ) percentage of overall dead birth by $23 \%$, and increases $(\mathrm{p}=0.050)$ overall percentage of live sheep by $59 \%$. In animal studies of mice, there were no data for differrences in the number of fetuses after administration of L-Arginine.

The weight of mice after L-Arginine administration more heavier, the probable cau- se was in the treatment group containing more fetuses, with fetal weight also heavier than the control group. In contrast to previous study on sheep, showed that the weight of sheep with L-Aginin treatment did not differ significantly when compared to the control group (Lassala et al., 2011).

The mean length of fetus in treatment group (Mean= 2.0; $\mathrm{SD}=0.41$ ) was significantly longer than the control group that (Mean=1.6; $\mathrm{SD}=0.41)$, and it was statistically significant $(\mathrm{p}=0.005)$. Mean fetus weight in treatment group $(\mathrm{Mean}=0.4 ; \mathrm{SD}=0.15)$ was significantly heavier than the control group (Mean=0.3; $\mathrm{SD}=0.08)$, and it was statistically significant $(\mathrm{p}=0.002)$.

This is consistent with previous research that L-Arginine, said to increase fetal weight, and improve fetal growth restriction conditions. A study by Ohta et al. (2017) reported in animal models of preeclampsia with L-Arginine administration in the mother, will improve hypertension and prevent elevated levels of endothelin-1, mRNA and sFlt-1. It also showed reduced hypertension, increased vascular function and increased 
fetal weight. The administration of L-Arginine will increase fetal weight (Satterfield et al., 2013; Elizabeth et al., 2015; Chen, 2016; Verma et al., 2018).

The mean weight of placenta in the treatment group (Mean=0.2; $\mathrm{SD}=0.05$ ) was significantly heavier than the control group (Mean=0.1; $\mathrm{SD}=0.04$ ), and it was statistically significant $(\mathrm{p}=0.003)$. Increased placental weight may be due to improvement of placental angiogenesis because the administration of L-Arginine dramatically improves placental blood flow and blood volume and increases nutrients from maternal to placenta and then into the fetus. Further increases the weight of the placenta and fetus in Animal studies of mice conducted reported results that L-Arginine increased NO concentrations and increased protein intake, this is thought to lead to increased placental weight as well as fetal weight (Roberts and Hubel, 2009; AlBayati, 2014).

Furthermore, active transport of the LArginine-NO pathway activates the carrier protein in the placental membrane microvilli causing an increase in placental weight (Ohta et al., 2017).

\section{Expression of Hypoxia Inducible} Factor 1 Alpha (HIF-1-A)

In the observation from immunohistochemical result was obtained the average expression of HIF-1-A group of mice models preeclampsia with L-Arginine was lower than Mice models of preeclampsia without administration of L-Arginin group. The statistical results showed that placental HIF-1-A expression in the treatment group was significantly lower than in the control group ( $\mathrm{p}<\mathrm{0.001}$ ). The result of the observation is in accordance with the hypothesis.

This result in according to Korkes study, that in preeclampsia HIF-1-A value increased 2.5-fold compare with no hypertensive control (Korkes et al., 2017).
Pathophysiology of preeclampsia involves maternal, fetal and placental factors. Abnormalities in placental development early in pregnancy, starting from inadequate trophoblast invasion to spiral artery, leading to decreased uteroplacental perfusion, causing placental hypoxia (Ibrahim and Khaled, 2014; Sánchez-Aranguren et al., 2014). Placental hypoxia will increase oxidative stress and activation of inducible-1 $\alpha$ indifference pathway (HIF-1-A).

Animal studies by Ohta et al. (2017), using animals model, and to confirm placental hypoxia conditions in preeclampsia mice model, examined HIF-1-A expression in the placenta. The expression of HIF-1-A increased significantly in trophoblast, labyrinth, and spongiotrophoblast regions.

Another study Verma et al. (2018), examining the expression of HIF-1-A, was determined as a percentage with immune staining (color: golden brown chromogen) within trophoblast villi. Increased HIF-1-A expression was associated with important gene dysregulation until dysregulated function normal placenta, so increased HIF-1-A expression is an important parameter for developing a new therapeutic strategy for preeclampsia (Robb et al, 2017).

The above studies are consistent with the results of this study, in which HIF-1-A expression of placenta in the treatment group with L-Arginine administration was lower than in control group. Administration of oral L-Arginine 200mg/ kgBW/ oral day 7-15 pregnancy, because of on 7 th day of pregnancy, the implantation process has been completed and the trophoblast placentation stage begins to the $15^{\text {th }}$ day of the placentation process is complete (Cheryl, 2015).

In preeclampsia a prolonged hypoxia due to spiral arteria remodeling failure, HIF1-A expression will increase and stimulate angiogenesis changes, imbalance of proangiogenic factor (VEGF and PlGF) and anti ang- 
iogenic (sENG, sFlt-1). Followed by oxidative stress processes that cause endothelial dysfunction in blood vessels and other symptoms of disorders, including hypertension (Asif and Wenda, 2015). In this placental hypoxia condition, a strong vasodilator is needed to prevent prolonged hypoxia, thus preventing worsening of symptoms from preeclampsia due to oxidative stress (Robb et al., 2017).

L-Arginine, as NO precursor, is a powerful vasodilator for improving placental hypoxia in preeclampsia, especially during placentation and angiogenesis.

NO is the main vasodilator that controls blood flow to the placenta and also the fetoplacental vessels. Much evidence suggests that NO is important for maintaining a low resistance / high flow uteroplacental system that supports nutrients, fetal oxygenation (Asif and Wenda, 2015). In preeclampsia there is a decrease in activity of Nitric Oxide (NO), endothelial nitric oxide (eNOS), and a decrease in the concentration of cationic amino acid L-Arginine, which is the substrate of eNOS (Grafka et al, 2016). In Lisette's study, Salsoso et al said NO levels decreased and ADMA increased in pregnancy with preeclampsia (Lisette, 2014).

A preclinical study conducted on mice showed that L-Arginine reduced the incidence of hypertension, in response to reduced uterine perfusion pressure in pregnant mice, suggesting that L-arginine supplementation was useful in management in the case of preeclampsia (Al-Bayati, 2014).

Other studies in rats and mice induced by preeclampsia, characterized by hypertension, proteinuria and fetal growth inhibition after administration, NG-nitro-L-Arginine Methyl Ester (L-NAME), an important inhibitor of NO synthase, improved after treatment with L-Arginine with reduced urinary protein excretion, a significant drop in blood pressure and restoration of glomeruli lesions.
L-Arginine plays a role through NO synthase pathway by inhibiting nitric oxide synthase inhibitor so that NO production will increase and can give effect of vascular vasodilation and improve hypoxia (Lisette, 2014). NO from the maternal circulation will cross into the placenta and dilate the vascular placental villi by increasing the vascularity of the villi, the lumen dilatation and the muscle walls of the blood vessels so as not to have atherosis or thickening. Good blood flow perfusion will prevent the ongoing hypoxia, thus improving the condition of placental hypoxia and improvement of symptoms of preeclampsia which in this study is characterized by low expression of HIF-1-A (Wall et al., 2014).

In addition, L-Arginine modulates cellular response to hypoxia by increasing the activity of Prolyl Hydroxylase (PHD) which will degrade HIF-1-A protein so that the amount decreases (Semenza, 2011).

In this study, researchers found that the use of L-Arginine dose of 200mg / $\mathrm{kgBW} /$ day/orally was effective in improving placental hypoxia condition of preeclampsia mice models characterized by lower expression of placental HIF-1-A as marker of placental hypoxia in admistration L-Arginine (case) group. It is also expected by L-Arginin administration, analogically will improve the symptoms of preeclampsia, and it can be analyzed that L-Arginin is a new therapy option to improve the condition of preeclampsia in human to prevent further complications.

\section{AUTHOR CONTRIBUTION}

Nutria Widya Purna Anggraini is the main researcher who formulated the conceptual framework, plays role in processing and collecting data of the study. Sri Sulistyowati examined conceptual framewok and methodology of the study. Besari Adi Pramono and Herman Kristanto gave the suggestion related to the discussion 


\section{CONFLICT OF INTEREST}

The authors state that there is no conflict of interest related to this study, the author, and the publication of this article

\section{FUNDING AND SPONSORSHIP}

This study used independent fund by the main researcher.

\section{ACKNOWLEDGEMENT}

The author would like to express their gratitude to the Head of Veterinary Reproduction Laboratory, Faculty of Veterinary Medicine, Airlangga University

\section{REFERENCE}

Al-Bayati MA, Ahmad MA, Khamas W (2014). The potential effect of l-argi-nine mice placenta. Adv Pharmaco-epidemiol Drug Saf, 3(2): 1-9. https://doi.org/0.4172/2167-1052.1000150.

Asif A and Wenda R (2015). Unraveling the theories of pre-eclampsia: are the protective pathways the new paradigm?. Br J Pharmacol, 172(6): 1574-86.

Burke S and Karumanchi (2013). A Spiral artery remodeling in preeclampsia revisited. Hypertension,(62) :1013-4.

Cheryl LML (2015). Female reproductive tract. In : A practical Guide Hystology of the Mouse. 6th ed. Milton (Australia): John Wiley 7 Sons, p.88-97.

Facchinetti F, Farulla A. (2017)Dietary suplements and drugs for preeclampsia prophylaxis. Journal of Women's Cardiovascular Health. (7): 59 https://doi.org/10.1016/j.preghy.2016.10.014.

Gao K, Jiang Z, Lin Y, Zheng C, Zhou G, Chen F, Wu G (2011). Dietary l-arginine supplementation enhances placental growth and reproductive performance in sows. Amino Acids, 42(6), 2207-2214. https://doi.org/10.1007/s00726-0110960-9.
Grafka A, Lopucki M, Karwasik-Kajszczarek K, Stasiak-Kosarzycka M, Miturski A, Dzida G (2016). Study of the role l- arginine in the diagnosis of pregnancy-induced hypertension Arterial Hypertens, 20 (3): 113-8.

Himpunan Kedokteran Fetomaternal (2017). Pedoman nasional pelayanan kedokteran tata laksana komplikasi kehamilan. Jakarta: Kementerian Kesehatan Republik Indonesia,hal. 23-48.

Kooffreh ME, Ekott M, Ekpoudom DO (2014). The prevalence of preeclampsia among pregnant women in the university of calabar teaching hospital, calabar. Saudi J Health Sci, (3):133-6. https://doi.org/10.4103/2278-0521.142317.

Korkes HA, De Oliveira L, Sass N, Salahuddin S, Karumanchi SA, Rajakumar A (2017). Relationship between hypoxia and downstream pathogenic pathways in preeclampsia. Hypertension in Pregnancy, 36(2), 145-150. https://doi.org/10.1080/10641955.2016.1259627.

Ibrahim NA, Khaled DM (2014). Histological and immunohistochemical study on human placental tissue in normal pregnancy and preeclampsia. Nat Cell Biol, 2(6): 72-80. https://doi.org/10.11648/j.cb.-20140206.13.

Lassala A, Bazer FW, Cudd TA, Datta S, Keisler DH, Satterfield MC, Spencer TE, et al (2011). Parenteral administration of l-arginine enhances fetal survival and growth in sheep carrying multiple fetuses. J Nutr, 141(5): 849-55. https://doi.org/10.3945/jn.111.13-8172.

Lyall F, Bellfort MA (2007). Preeclampsia: etiology and clinical practice. New York: Cambridge University Press.

Ohta H, Kaga M, Li H, Sakai H, Okamura K, Yaegashi N (2017). Potential new non-invasive therapy using artificial oxygen carriers for preeclampsia. $\mathrm{J}$ 
Anggraini et al./ Effect of L- Arginin on Placental Hipoxia Inducible Factor -1-Alpha

Funct Biomater. 8(3): 32. https://doi-.org/10.3390/jfb8030032.

Patel J, Landers K, Mortimer RH, Ricard K (2010). Regulation of hypoxia indu-cible factors (HIF) in hypoxia and normoxia during placental development. Placenta. 31(11): 951-7. https://doi.org/10.1016/j.placenta.2010.08.008.

Provincial Health Office of Central Java (2015). Profil kesehatan provinsi jawa tengah tahun 2015[internet]. Available from: https://www. Dinkesjatengprov.go.id/v2015/dokumen/profil2015/.

Robb KP, Cotechini T, Allaire C, Sperou A, Graham CH (2017). Inflammation-induced fetal growth restriction in rats is associated with increased placental HIF-1 $\alpha$ accumulation. Plos One, 12(4), e0175805. https://doi.org/10.1371/journal.pone.0175805.

Sánchez-Aranguren LC, Prada CE, RiañoMedina CE, Lopez M (2014). Endothelial disfunction and preeclampsia: role of oxidative stress. Front Physiol. (5): 372. https://doi.org/10.3389-\%2Ffphys.2014.00372.

Tal R (2012). The role of hypoxia and hypoxia inducible factor 1 alpha in preeclampsia pathogenesis. Biol Reprod, 87(6): 1-8. https://doi.org/10.1095/-biolreprod.112.102723.

Roberts JM, Hubel CA (2009). The two stage model of preeclampsia: variations on the theme. Placenta. (23): 32-7. https://doi.org/10.1016\%2-Fj.placenta.2008.11.009.

Roberts MD, Phyllis A (2013). Task force on hypertension in pregnancy. In: Hy-pertension in pregnancy. ACOG. (2): 1-11. Available from: https://www.-acog.org/Clinical/Taskforce.

Semenza G (2011). Hypoxia inducible factor 1: ;Regulator of mitochondrial metabolism and mediator of ischemic pre- conditioning. Biochim Biophys Acta. 13(7): 1263-8.

Soetrisno S, Sulistyowati S, Wibowo AS (2017). L-arginine improves uterine spiral arterial wall thickness in mouse model of preeclampsia. Univ Med. 36 (2):1317.

Supranto J (2010). Teknik sampling untuk survey dan eksperimen. Jakarta: PT. Rineka Cipta.

Verma S, Pillay P, Naicker T, Moodley J, Mackraj I (2018). Placental hypoxia inducible factor-1 $\alpha$ \& CHOP immuno-histochemical expression relative to maternal circulatory syncytiotropho-blast micro-vesicles in preeclamptic and normotensive pregnancies. Eur J Obstet Gynecol Reprod Biol. 220: 18-24. https://doi.org/10.1016/j.ejogrb.-2017.11.o04.

Wall TD, Grivell RM, Dekker GA, Hague W, Dodd JM (2014). The role of L-Argi-nin in the prevention and treatment of preeclampsia: a systematic review of randomised trials. J Hum Hyper-tens, 28(4): $230-5$.

Wantania J, Bakri S, Pandelaki K, Chalid M (2013). Altered level of soluble fms-like tyrosine kinase 1 (sFlt1) and hy-poxia inducible factor-1alpha (HIF-1Alpha) in normotensive pregnancy and preeclampsia. Indones Biomed J. 5(2): 121-8. https://doi.org/10.18585/inabj.v5i2.61.

Woods AK, Hoffmann DS, Weydert CJ, Butler SD, Zhou Y, Sharma RV, Davisson RL (2011). Adenoviral delivery of vegf 121 early in pregnancy prevents spontaneous development of preeclampsia in bph/5 mice. Hypertension. 57(1): 94102. https://doi.org/10.1161/hypertensionaha.110.160242. 